\title{
Daya Hambat Ekstrak Daun Pegagan (Centella asiatica) yang Diambil di Batusangkar terhadap Pertumbuhan Kuman Vibrio cholerae secara In Vitro
}

\author{
Nelvita Sari Ramadhan ${ }^{1}$, Roslaili Rasyid ${ }^{2}$, Elmatris $\mathrm{Sy}^{3}$
}

\begin{abstract}
Abstrak
Pegagan (Centella asiatica) merupakan salah satu tanaman yang digunakan sebagai obat. Salah satu manfaat yang bisa didapatkan dari pegagan (Centella asiatica) adalah antibakterinya. Manfaat antibakterinya didapatkan karena pegagan (Centella asiatica) mengandung zat antibakteri, diantaranya adalah saponin, tannin, alkaloid, dan flavonoid. Telah dilakukan penelitian tentang daya hambat ekstrak pegagan (Centella asiatica) terhadap pertumbuhan Vibrio cholerae secara in vitro, dengan tujuan untuk mengetahui daya hambat ekstrak pegagan (Centella asiatica) terhadap pertumbuhan Vibrio cholera secara in vitro. Penelitian dilakukan dengan metode eksperimental laboratorium dengan metode difusi (cakram), pada berbagai konsentrasi yaitu 5\%, 10\%, 20\%, 30\%, 40\%, 50\%, dan100\%, di Laboratorium Mikrobiologi Fakultas Kedokteran Universitas Andalas. Hasil penelitian didapatkan bahwa ekstrak daun pegagan (Centella asiatica) yang diambil di daerah Batusangkar, ternyata tidak dapat menghambat pertumbuhan kuman Vibrio cholerae secara in vitro, sedangkan tetrasiklin yang digunakan sebagai kontrol positif memberikan daya hambat yang baik terhadap pertumbuhan Vibrio cholera, dengan zona hambat 16,3 mm. Ada atau tidaknya daya hambat ekstrak pegagan (Centella asiatica) terhadap pertumbuhan Vibrio cholerae dalam penelitian ini bisa dipengaruhi oleh jenis bakteri yang digunakan, metode pembuatan ekstrak yang dipakai, dan sumber daun pegagan yang digunakan dalam penelitian.
\end{abstract}

Kata kunci: efek antibakteri, ekstrak daun pegagan (Centella asiatica), Vibrio cholerae

\section{Abstract}

Centella asiatica is one of the plants used as medicine. One of the benefits that can be obtained from Centella asiatica is an antibacterial effect. Antibacterial effect obtained as Centella asiatica contains anti-bacterial substances, such as saponins, tannins, alkaloids, and flavonoids. This study was conducted to determine the inhibition of extracts of Centella asiatica on the growth of Vibrio cholerae in vitro. The study was conducted with laboratory experimental method with diffusion method (disc), at various concentrations of $5 \%, 10 \%, 20 \%, 30 \%, 40 \%, 50 \%$, and $100 \%$, in the Laboratory of Microbiology, Faculty of Medicine, University of Andalas. The results showed that extractof Centella asiatica were taken in Batusangkar, did not inhibit the growth of Vibrio cholerae in vitro, whereas tetracycline is used as a positive control gave good inhibition of the growth of Vibrio cholerae, the inhibition zone16, 3mm. Factors influencing the presence or absence of inhibition of Centella asiatica on extracts the growth of Vibrio cholerae, among others, is a type of bacteria used, the method of making the extract used, and the source of Centella asiatica leaves are used in research.

Keywords:antibacterial effects, Centella asiatica extract, Vibrio cholerae

Affiliasi penulis : 1. Pendidikan Dokter FK UNAND (Fakultas Kedokteran Universitas Andalas Padang), 2. Bagian Mikrobiologi FK UNAND, 3. Bagian Kimia FK UNAND

Korespondensi : Nelvita Sari Ramadhan, E-mail: sarinelvita@yahoo.co.id, Telp: 085274827286

\section{PENDAHULUAN}

Indonesia dikenal sebagai negara dengan sumber daya alam kedua terbesar setelah Brasil. Sumber daya alam tersebut tersebar dari Sabang 
sampai Merauke. Indonesia mempunyai sekitar 30.000 jenis tumbuhan dari 40.000 jenis tumbuhan di dunia. 940 jenis diantaranya dapat dimanfaatkan untuk obat (jumlah ini merupakan $90 \%$ dari jumlah tumbuhan obat di Asia). Banyaknya jenis tanaman obat, hanya sekitar $20 \%-22 \%$ yang dibudidayakan, sedangkan78\% lainnya diperoleh melalui pengambilan langsung dari hutan.

Meningkatnya minat masyarakat terhadap obat tradisional, ditandai banyaknya obat tradisional yang beredar di masyarakat. Menurut BPOM RI, pada tahun 2011 terdapat sekitar 1.626 nomor izin edar (NIE) obat tradisional yang sudah dikeluarkan. NIE yang dikeluarkan terdiri dari 1.395 NIE untuk obat tradisional lokal dan 217 NIE untuk obat tradisional impor, serta 14 NIE untuk obat tradisional lisensi. ${ }^{2}$

Obat tradisional Indonesia merupakan salah satu warisan budaya bangsa yang perlu dilestarikan, diteliti, dan dikembangkan lagi. Penelitian untuk obat tradisional sudah banyak dilakukan. Banyaknya penelitian terhadap obat-obatan tradisional, diharapkan dapat memajukan pengobatan tradisional. ${ }^{3}$

Pegagan merupakan salah satu tanaman yang berkhasiat untuk obat dan sering digunakan untuk pengobatan tradisional, seperti untuk obat antidiare. Tumbuhan yang memiliki nama latin Centella asiatica, sering dijumpai di tempat yang terbuka, pada tanah yang lembab dan subur seperti di pematang sawah, di padang rumput, dipinggir parit, dan di pinggir jalan. ${ }^{4}$

Pegagan mengandung zat kimia diantaranya adalah asiaticoside (termasuk bagian dari saponin), yang memiliki manfaat untuk penyembuhan luka dan juga antilepra. Manfaat lain dari tanaman ini adalah untuk pengobatan diare, disentri, epilepsi dan juga untuk peningkatan daya ingat. ${ }^{5}$ Berdasarkan penelitian $S$ Shakir Jamil et al, bahwa pegagan juga memiliki manfaat untuk pengobatan ulkus lambung, memiliki efekneuroprotektif, kardioprotektif, radioprotektif dan hepatoprotektif, sebagai antioksidan, antiinflamasi, antiansietas, memperbaiki kerusakan vena dan arteri, serta sebagai antistres. ${ }^{6}$

Kandungan triterpenoid/saponin pada pegagan dapat meningkatkan aktivasi makrofag. Meningkatnya aktivasi makrofag akan meningkatkan kemampuan fagositosis dan sekresi interleukin, sehingga memacu sel B untuk menghasilkan antibodi terhadap antigen yang masuk ke dalam tubuh. ${ }^{7}$

Pegagan juga mempunyai efek antibakteri. Kandungan pegagan yang berfungsi sebagai antibakteri, antara lain saponin. Menurut penelitian J. Barnes dkk pada tahun 1996 bahwa derivat saponin, asiaticoside bersifat lipofilik dan dapat membentuk senyawa kompleks dengan membran sel melalui ikatan hidrogen, lalu menghancurkan permeabilitas dinding sel bakteri.

Berdasarkan penelitian Syahnida di tahun 1993, menunjukkan bahwa ekstrak daun pegagan bisa menghambat pertumbuhan Pseudomonas aeruginosa, Enterobacter aerogenes dan Salmonella typhi. Menurut penelitian NS Jagtap dkk, ekstrak tumbuhan pegagan memiliki efek antibakteri terhadap Staphylococcus aureus, Escherichia coli, Bacillus subtilis, dan Propionibacterium vulgaris. Selain sebagai antibakteri, pegagan juga bisa dimanfaatkan sebagai antijamurterhadap Aspergillus niger, Aspergillus flavus, dan Candida albicans. ${ }^{8}$

Diare merupakan salah satu penyakit yang disebabkan oleh bakteri. Diare termasuk salah satu penyebab kematian tersering di dunia. Data dari WHO mengatakan bahwa diare merupakan salah satu penyebab kematian pada anak di bawahusia limatahun. Setiap tahun diare membunuh sekitar 760.000 anak balita. Diare banyak mengenai anakanak, karena daya tahan tubuh mereka yang masih belum sempurna dibandingkan orang dewasa, sehingga lebih rentan terinfeksi bakteri dan sumber penyakit lainnya. Diarejuga menjadi penyebab utama gizi buruk pada anak di bawah usia lima tahun. ${ }^{9}$

Secara global, diperkirakan ada sekitar 1,7 miliar kasus diare setiap tahun.Di Indonesia, menurut data dari Kemenkes RI pada tahun 2012, diare menempati peringkat pertama terbanyak pasien rawat inap di rumah sakit tahun 2010, dari 71.889 pasien yang dirawat, 1.289 diantaranya meninggal dunia. Tahun 2011 diperkirakan ada sekitar 9.739.163 kasus diare di seluruh provinsi Indonesia. Di Sumatera Barat, berdasarkan data dari Dinas Kesehatan Sumatera Barat, diperkirakan ada sekitar 115.551 kasus pada tahun 2010 dan mengalami sedikit penurunan pada 
tahun 2011 menjadi 100.780 kasus. $^{10}$

Penyebab diare, salah satunya adalah Vibrio cholerae, yang disebut juga dengan kolera, dimana penularannya bisa melalui air atau makanan. Reservoir alami bakteri ini diperkirakan di lingkungan perairan. Masyarakat Indonesia rentan untuk terinfeksi bakteri ini, karena sebagian besar masyarakat bekerja di lingkungan perairan seperti petani dan nelayan. Vibrio cholerae memiliki lebih dari 200 serotipe, tetapi yang paling utama penyebab diare adalah Vibrio cholerae 01 dan Vibrio cholerae 0139. Saat ini, Vibrio cholerae O1biotipeEI Tor merupakan penyebab kolera yang paling dominan di dunia. ${ }^{11,12}$

Kasus kolera banyak ditemui di negara berkembang, karena masih kurangnya sumber air bersih dan sanitasi lingkungan yang masih buruk. Di negara maju seperti Amerika Serikat, kolera tidak menjadi ancaman yang begitu berarti karena sanitasinya bagus dan ketersedian air bersih yang memadai, kecuali bagi para wisatawan yang mengunjungi daerah endemi, yang tertular dan menyebarkannya di negara asalnya. ${ }^{12}$

Angka kejadian yang tinggi membuat kolera termasuk salah satu penyakit yang harus dilaporkan kepada WHO. Tidak lengkapnya laboratorium, rendahnya tingkat perawatan dan pengawasan medis, serta tidak memadainya pendataan, megakibatkan kasus diare yang dilaporkan hanya mewakili sekitar 5$10 \%$ dari jumlah kasus yang sebenarnya terjadi setiap tahun di seluruh dunia. Faktanya, sekitar 3-5 juta kasus kolera setiap tahunnya terjadi di dunia dan sekitar 100.000-120.000 kasus diantaranya berakhir dengan kematian. Tahun 2011, 589.854 kasus kolera telah dilaporkan kepada WHO oleh 58 negara, dengan 7.816 kematian. $^{13,14}$

Berdasarkan hal di atas serta adanya penelitian yang menunjukkan adanya efek antibakteri ekstrak daun pegagan terhadap Escherichia coli, Salmonella thipy, Pseudomonas aeruginosa dan
Enterobacteraerogenes yang merupakan kelompok bakteri batang Gram Negatif, maka peneliti termotivasi untuk meneliti efek antibakteri ekstrak daun pegagan terhadap pertumbuhan Vibrio cholerae, yang juga termasuk kelompok bakteri batang Gram Negatif.

Penelitian ini bertujuan untuk mengetahui daya hambat ekstrak pegagan (Centella asiatica) terhadap pertumbuhan Vibrio cholerae secara in vitro.

\section{METODE}

Penelitian dilakukan dengan metode eksperimental laboratorium dengan metode difusi (cakram) di Laboratorium Mikrobiologi Fakultas Kedokteran Universitas Andalas pada bulan Januari 2014. Variabel adalah ekstrak daun pegagan dengan berbagai konsentrasi yaitu 5\%, 10\%, 20\%, 30\%, 40\%, $50 \%$, dan $100 \%$ dan kuman Vibrio cholerae. Bahan yang digunakan dalam penelitian ini adalah daun pegagan, biakan murni kuman Vibrio cholerae, agar TCBS, ethanol $96 \%, \mathrm{NaCl} 0,9 \%$ dan tetrasiklin sebagai kontrol positif. Alat yang digunakan dalam penelitian ini adalah cawan petri, kertas saring, gelas ukur, pelubang kertas, lampu spritus, lem, jarum ose, lidi kapas steril, inkubator, pinset, pisau, mistar, spuit disposable, autoklaf, rotary evaporator, corong Buchner, cakram (paper disc), Erlenmeyer, standar, neraca teknis, kertas perkamen, mixer (pengaduk). Data hasil penelitian diolah secara statistik dengan metode Anova satu arah dengan derajat kepercayaan $95 \%(=0,05)$ dan bila didapat perbedaan nyata antar perlakuan maka akan dilanjutkan dengan Post Hoc Test dengan taraf kesalahan $1 \%$.

\section{HASIL}

Penelitian mengenai daya hambat ekstrak daun pegagan terhadap pertumbuhan kuman Vibrio cholerae dan Escherichia coli, didapatkan hasil sebagai berikut. 
Tabel 1. Daya Hambat Ekstrak Daun Pegagan terhadap Pertumbuhan Vibrio cholerae

\begin{tabular}{|c|c|c|c|c|}
\hline \multirow{2}{*}{ Perlakuan } & \multicolumn{3}{|c|}{$\begin{array}{l}\text { Diameter Bebas Kuman } \\
(\mathrm{mm})\end{array}$} & \multirow{2}{*}{$\begin{array}{c}\text { Diameter } \\
\text { Bebas } \\
\text { Kuman } \\
\text { Rata- } \\
\text { rata } \\
(\mathrm{mm})\end{array}$} \\
\hline & I & II & III & \\
\hline $\begin{array}{l}\text { Kontrol Positif } \\
\text { (Tertrasiklin) }\end{array}$ & 15 & 16,5 & 17,5 & 16,3 \\
\hline \multicolumn{5}{|c|}{ Ekstrak daun pegagan } \\
\hline $5 \%$ & - & - & - & - \\
\hline \multicolumn{5}{|c|}{ Ekstrak daun pegagan } \\
\hline $10 \%$ & - & - & - & - \\
\hline \multicolumn{5}{|c|}{ Ekstrak daun pegagan } \\
\hline $20 \%$ & - & - & - & - \\
\hline \multicolumn{5}{|c|}{ Ekstrak daun pegagan } \\
\hline $30 \%$ & - & - & - & - \\
\hline \multicolumn{5}{|c|}{ Ekstrak daun pegagan } \\
\hline $40 \%$ & - & - & - & - \\
\hline \multicolumn{5}{|c|}{ Ekstrak daun pegagan } \\
\hline $50 \%$ & - & - & - & - \\
\hline \multicolumn{5}{|c|}{ Ekstrak daun pegagan } \\
\hline $100 \%$ & - & - & - & - \\
\hline
\end{tabular}

Dari tabel diatas didapatkan hasil bahwa ekstrak daun pegagan dalam berbagai konsentrasi tidak menghasilkan daerah bebas kuman pada pertumbuhan Vibrio cholerae secara in vitro, berarti tidak ada daya hambat ekstrak daun pegagan terhadap pertumbuhan kuman Vibrio cholerae secara in vitro di dalam penelitian ini.

Tetrasiklin menghasilkan daerah bebas kuman, berarti tetrasiklin bisa menghambat pertumbuhan Vibrio cholerae, dengan kata lain Vibrio cholerae yang digunakan tidak resisten terhadap tetrasiklin.

\section{PEMBAHASAN}

Faktor yang mempengaruhi ada atau tidaknya daya hambat ekstrak pegagan, antara lain adalah jumlah kandungan zat antibakteri yang dikandung pegagan. Zat antibakteri yang dimaksud adalah saponin, tannin, alkaloid, dan flavonoid. Ada atau tidaknya daya hambat ekstrak pegagan terhadap Vibrio cholerae tergantung kepada jumlah zat antibakteri yang ada pada ekstrak pegagan. Apakah zat antibakteri yang dimaksud ada atau apakah jumlahnya mencukupi untuk menghambat pertumbuhan kuman Vibrio cholerae?
Banyak faktor yang mempengaruhi jumlah kandungan zat yang terbentuk pada tanaman. Menurut penelitian Nurliani Bermawie $d k k$, pada tahun 2008, faktor jenis tanah atau daerah juga mempengaruhi kandungan zat yang terbentuk pada tanaman. $^{15}$ Misalnya, pada penelitian Thangavel Arumugam dkk, pada tahun 2011, zat yang terkandung dalam pegagan yang diambil dari Taman Obat Universitas VIT, India, adalah saponin, tannin, terpenoid, dan zat lainnya sedangkan flavonoid tidak ditemukan. Penelitian lain dilakukan dengan menggunakan daun pegagan yang diambil didaerah lain di India, ternyata pegagan tersebut tidak mengandung saponin. ${ }^{16}$

Bakteri yang digunakan dalam penelitian ini juga menentukan ada atau tidak daya hambat yang ditimbulkan zat antibakteri yang dikandung ekstrak pegagan. Perbedaan strain bakteri menyebabkan perbedaan enzim atau zat lain yang dihasilkan oleh bakteri. Perbedaan enzim atau zat lainnya akan memberikan efek yang berbeda terhadap zat antibakteri yang dikandung pegagan. Enzim yang dihasilkan oleh bakteri bisabersifat racun terhadapzat antibakteri, sehingga menonaktifkan zat tersebut, bisa juga menghancurkan atau merusak zat itu. ${ }^{17}$

Perbedaan strain disebabkan oleh perbedaan antigen.Vibrio cholerae ditemukan lebih dari 200 serogrup yang berasal dari antigen $\mathrm{H}$ dan antigen $\mathrm{O}$, dimana antigen $\mathrm{O}$ memiliki lipopolisakarida sedangkan antigen $\mathrm{H}$ tidak. $^{17}$

Perbedaan varietas pegagan, teknik prosesing dan teknik analisis juga berpengaruh terhadap perbedaan hasil penelitian. Perbedaan proses pembuatan ekstrak yang digunakan juga menghasilkan hasil yang berbeda pula. Contohnya, pertumbuhan Escherichia coli terhambat pada ekstrak petroleum ether, sedangkan pada ekstrak n-Hexana tidak terlihat adanya hambatan pertumbuhan kuman. ${ }^{18}$

Ada atau tidaknya daya hambat ekstrak pegagan (Centella asiatica) terhadap pertumbuhan Vibrio cholerae dalam penelitian ini bisa dipengaruhi oleh jenis bakteri yang digunakan, metode pembuatan ekstrak yang dipakai dan sumber daun pegagan yang digunakan dalam penelitian. 


\section{KESIMPULAN}

Tidak ditemukan daya hambat ekstrak daun pegagan yang diambil di Batusangkar, terhadap pertumbuhan kuman Vibrio cholerae secara in vitro. Perlu dilakukan penelitian lebih lanjut lagi tentang daya hambat ekstrak daun pegagan terhadap pertumbuhan kuman Vibrio cholerae menggunakan metode yang berbeda, jenis pegagan yang berbeda, serta menggunakan strain bakteri yang berbeda dari penelitian ini.

\section{DAFTAR PUSTAKA}

1. Kementerian Kehutanan Republik Indonesia (Kemenhut RI). Lokakarya nasional tanaman obat Indonesia. Jakarta:2010.

2. Badan Pemeriksa Obat dan Makanan Republik Indonesia (BPOM RI). Laporan akuntabilitas kinerja instansi pemerintah (LAKIP) 2011. Jakarta: 2011.

3. Dewoto HR. Pengembangan obat tradisional indonesia menjadi fitofarmaka. Maju Kedokteran Indonesia. 2007: 57(7).

4. Badan Pemeriksa Obat dan Makanan Republik Indonesia (BPOM RI). Acuan sediaan herbal. 2010:5(1).

5. Orhan IE. Centella asiatica (L.) Urban: from traditional medicine to modern medicine with neuroprotective potential. Evid Based Complement Alternat Med. 2012.

6. Jamil SS, Nizami Q, Salam M. Centella asiatica (Linn) urban óa review. Natural Product Radianc. 2007;6(2):158-70.

7. Besung INK. Pegagan (Centella asiatica) sebagai alternatif pencegahan penyakit infeksi pada ternak. Buletin Veteriner Udayana.2009;1(2):61-7.

8. Jagtap NS, Khadabadi SS, Ghorpade DS, Banarase NB, Naphade SS. Antimicrobial and antifungal activity of centella asiatica (I.)urban, umbeliferae. Research J. Pharm. and Tech. 2009; 2(2).

9. WHO. Diarrhoeal Disease. 2013 (diunduh 14 Februari 2013). Tersedia dari: URL: HYPERLINK http://www.who.int/mediacentre/factsheets/fs330/e $\mathrm{n} /$ index.html.

10. Kementerian Kesehatan Republik Indonesia (Kemenkes RI) Profil data kesehatan Indonesia tahun 2011. Jakarta: 2012.

11. Todar K. Vibrio cholerae and Asiatic cholera. Todar's Online Textbook of Bacteriology. 2008 (diunduh 12 Februari 2013).Tersedia dari: URL: HYPERLINK http://textbookofbacteriology.net/ cholera.html.

12. Thaker VV. Cholera. Medscape Reference. 2011 (diunduh 25 Februari 2013). Tersedia dari: URL: HYPERLINK http://emedicine.medscape.com/ article/962643-overview\#a0104.

13. Ali M, Lopez AL, You YA, Kim YE, Sah B, Maskery $B$, et al. The global burden of cholera. Bulletin of the World Health Organization. Past issues. 2012; 90:209-18.

14. WHO. Cholera. 2012 (diunduh 14 Februari 2013). Tersedia dari: URL: HYPERLINK http://www.who. int/mediacentre/factsheets/fs107/en/index.html.

15. Bermawie N, Purwiyanti S, Mardiana. Keragaman sifat morfologi, hasil dan mutu plasma nutfah pegagan (centella asiatica (L.) Urban.) Bul. Littro. 2008; 19 (1): 1 - 17.

16. Arumugam T, Ayyanar M, Pillai YJK, Sekar T. phytochemical screening and antibacterial activity of leaf and callus extracts of centella asiatica. Bangladesh J Pharmacol. 2011; 6:55-60.

17. Jawetz, Melnick, Adelberg. Mikrobiologi Kedokteran. Dalam: Nugroho AW, Ramadhani D, Santasa H, Yesdelita N, Nirmala WK, editor (penyunting). Vibrio, Campylobacter, Helicobacter dan Bakteri Sejenis. Edisi ke-25. Jakarta: EGC; 2012. hlm. 248-55.

18. Dash BK, Faruquee HM, Biswas SK, Alam MK, Sisir SM, Prodhan UK. Antibacterial and Antifungal Activities of Several Extracts of Centella asiatica L. against Some Human Pathogenic Microbes. Life Sciences and Medicine Research. 2011; 2011: LSMR-35. 